\title{
Research on Innovation and Entrepreneurship Education in Local Engineering University
}

\author{
Liangtao Yang \\ Engineering \& Training Center \\ Shanghai Polytechnic University \\ Shanghai, China \\ E-mail:ltyang@sspu.edu.cn
}

\begin{abstract}
The innovative and entrepreneurial ability is an important manifestation of the comprehensive quality of college students. Shanghai Second Polytechnic University as a local engineering university, according to creating a good innovation and entrepreneurship atmosphere, setting up practice platform for innovation and entrepreneurship education, promoting innovation and entrepreneurship teachers' team, carries out college students' innovation education in-depth. These measures are effective in practice, and it is of great significance to the innovation and entrepreneurship education in local engineering universities.
\end{abstract}

Keywords - innovation and entrepreneurship education ; local engineering university; practice platform; curriculum system

\section{INTRODUCTION}

Cultivating students' innovative and entrepreneurial ability is an important content of personnel training, and also an important indicator to measure the quality of personnel training. To strengthen the cultivation of College Students' innovative and entrepreneurial ability can promote the construction of innovative country, so as to better adapt to the regional economic and social development and national strategic needs. Innovation and entrepreneurship education is a new mode of education to meet the needs of economic and social construction and the development of higher education itself. [1]How to effectively carry out the innovation and entrepreneurship education in Colleges and universities? How to cultivate the innovative spirit, innovative ability and a good sense of entrepreneurship and entrepreneurial ability is a new task for the education workers in Colleges and universities. Shanghai Second Polytechnic University has always attached great importance to the innovation and entrepreneurship education of college students, the combination of College Students' innovative entrepreneurship education and career oriented higher education educational philosophy depth in carrying out innovation and entrepreneurship students do a new entrepreneurial atmosphere of entrepreneurship education, curriculum, business practice has platform, business projects have a mentor, to build a training of entrepreneurship education curriculum based to street business practical operation to enhance, to a business expert escort for the protection of College Students' entrepreneurship education system. Through the exploration and practice of College Students' innovation and entrepreneurial ability to change the concept of education, reform the talent training mode, so as to promote the construction of innovative country to meet the needs of a high level of innovation and entrepreneurship personnel training.

\section{GOOD ATMOSPHERE OF INNOVATION AND ENTREPRENEURSHIP}

The atmosphere of campus culture is the most closely related to the cultural field, which has the function of internalization. Colleges and universities should carry out innovation and entrepreneurship education, and create a strong cultural atmosphere in the campus innovation and entrepreneurship. To this end, our university has taken a series of measures to create a good campus culture atmosphere, so that the majority of students attach great importance to and actively participate in innovation and entrepreneurship education. [2]

Around the goal of "innovation driven, transformation and development" and the goal of "modern applied characteristic university", Shanghai Second Polytechnic University actively promotes innovation and entrepreneurship education. We emphasize innovation and entrepreneurship education for all students, the school faculty, teaching through the mobilization of the whole process of educating. Our university has established the education philosophy of people-oriented, all-round development. We put innovation and entrepreneurship education into various disciplines and educational activities, and create a campus culture of respecting for innovation, encouraging entrepreneurship. Our university adopts a variety of ways and means to create a promotion, respect and attach importance to the students the spirit of innovation and entrepreneurship, campus cultural atmosphere, and through a variety of media and forms for teachers and students to carry out creative education, guide students to pursue innovation and entrepreneurship as the value orientation and to stimulate students' spirit of innovation and entrepreneurial enthusiasm. In the campus culture lecture, we organize the "principal forum", "forum", "model worker road" and "alumni talk". Through lectures, and actively invite outside the school, at home and abroad, the social from all walks of life well-known scholars and model workers alumni come to the school, and the majority of school teachers and students face to face communication, the connotation of innovation and entrepreneurship education full range into the campus culture.

Student associations play an important role in cultivating students' sense of innovation and practical ability, guiding students to become a useful talent, forming a good innovation, 
entrepreneurial campus culture, and so on. Our university strengthens the construction of student entrepreneurial associations, organizes the entrepreneurial activities, and creates a strong scientific research, innovation and entrepreneurship campus atmosphere. [3] To cultivate students' innovation and entrepreneurship awareness, our university makes full use of community activities to carry out the competition of science and technology; stimulates students' enthusiasm of innovation and entrepreneurship by social practice; enhance the students' power of innovation and entrepreneurship. The student associations are led by students, the school provide hardware environment, and with the guidance of teachers, the student team is responsible for the daily operation and management of the associations. According to personal interest, Students can enter the association. By short project design, curriculum design, emphasizing the senior and junior students pass, side, belt, students can learn a lot of knowledge about innovation and entrepreneurship through learning, communication, practice in the short time. Through various forms of Academic Salon, academic reports, lectures, academic competitions and activities, all associations increase exchanges between students, between students and teachers, so that we can find the same interests with their partners. At present, the school has more than 20 kinds of science and technology associations, the main function is to popularize the basic knowledge of innovation and entrepreneurship, to carry out scientific and technological innovation, academic exchange activities, and create a campus cultural atmosphere of innovation and entrepreneurship.

\section{HIERARCHICAL COURSES OF INNOVATION AND ENTREPRENEURSHIP}

Innovation and entrepreneurship education is a comprehensive knowledge system. The university has carried on the thorough demonstration to the existing 37 undergraduate major, 20 higher vocational colleges. Our university put innovation and entrepreneurial ability into the personnel training plan, and runs through the entire personnel training process. The university penetrates innovation and entrepreneurship education into the whole process of teaching. By the integration of all kinds of curriculum resources, our university constructs the curriculum system of innovation and entrepreneurship education, puts the innovation and entrepreneurship education curriculum into compulsory course, improves the knowledge and ability structure of students' innovation and entrepreneurship, and has set up a multi-level, mingled with the innovation and entrepreneurship education curriculum system.

Innovation and entrepreneurship courses are divided into three levels according to the different educational objects. One is the general education courses of innovation and entrepreneurship courses for all students. The course for all college students in the form of a compulsory course, all students must accept the innovation and entrepreneurship education to train the basic quality of innovation and Entrepreneurship. For example, the opening economic contract, marketing, human resource management and other courses, these courses train students' sense of innovation and entrepreneurship, so that college students can establish a scientific concept of innovation and entrepreneurship, and actively participate in innovation and entrepreneurship practice. [4]

Two is innovation and entrepreneurship courses according to different students. The curriculum can meet the students' individualized learning for innovation and entrepreneurship awareness and good potential in innovation and entrepreneurship. According to the different professional background, we open university students analysis and career development, the practice of entrepreneurship and innovation, venture management etc., and the courses enable students systematically master the innovation and entrepreneurship basic knowledge, dialectical understanding and analysis of innovation and entrepreneurship resources, innovative business plan and innovation and entrepreneurship program, help the students possess the entrepreneurial opportunity judgment, entrepreneurial team, entrepreneurship project management methods. [5]

Three is practice course of innovation and entrepreneurship for minority students. The course is mainly for high comprehensive quality, strong sense of entrepreneurship, innovation and risk students. By using the specific project as a guide, The course make students obtain the direct experience of the innovation and entrepreneurship in a simulated environment, experience in the process of innovation and entrepreneurship, grasp the resources integration and innovation and writing method of entrepreneurship program. Our employment guidance center invited the Shanghai Municipal People's Insurance Bureau, the Social Security Bureau to organize college students' entrepreneurship awareness and ability training. The teachers of special training are the shanghai innovation and entrepreneurship experts. The training contents include entrepreneurship policy, project screening, market assessment, plan writing, team construction and management, enterprise decision-making and the demand for funds and resources integration application. The training guide the participants themselves exercise implement the various steps of the enterprises run, complete the business plan and provide follow-up support services, help them to create a survival ability of small businesses.

As an application-oriented university, Shanghai Second Polytechnic University attaches treat importance to innovation and entrepreneurship education which is important content for teaching management and teaching reform management. At present, our university is actively pursuing the reform of credit system, undergraduate age relaxed to 3-6 years or longer period, allows adjusting the learning process, students can accelerate learning to early entrepreneurship, also can choose in the school business to extend the graduation time. From September this year, the compression of credit hours, the original undergraduate professional 190 points 220 credits, compressed to 150 points, to leave enough time for students to carry out entrepreneurial learning and practice. For the 2015 undergraduate freshmen, our university launches a new training program; all students require 4 credits of innovation and entrepreneurship". Unlike previous innovation courses, the major innovative work "in the curriculum teaching training and foundation to improve the students' innovation consciousness, pay more attention to theory application and the practice of innovation and achievements to culture and identify the ability 
of innovation and entrepreneurship, the identification results of content including high level papers, entrepreneurial projects, authorized patent, innovation works etc.. Students only need to finish four credits in 6 years of flexible educational system. This also means that students from the freshman when you need to cultivate the innovative thinking, and actively participate in innovation and entrepreneurship practice, under the guidance of the teacher's inspiration, achieve mastery through a comprehensive study of the innovation theory, apply their knowledge, make a determination results, so as to effectively enhance the ability of innovation and entrepreneurship and employment competitiveness.

\section{KINDS OF PRACTICE PlatForm FOR INNOVATION AND ENTREPRENEURSHIP EDUCATION}

Innovation and entrepreneurship education should be implemented by the practice of multi forms and multi channels. Through the integration of internal and external resources, our university builds a platform for innovation and entrepreneurship practice; establish students' innovation and entrepreneurship practice base to provide a good practical training platform and innovative entrepreneurial activity space, let the students learn, practice, innovate.

First, our university establishes the innovation base of university students. High level discipline competition has a great effect on the cultivation of students' innovative and entrepreneurial ability. Discipline competition is extremely beneficial for enhancing the students' ability of applying the knowledge, practical ability and planning ability. Our university combines the innovation competition and talent training, discipline construction, teaching reform, practice teaching, guides the students to design and participate in all kinds of academic competition and innovation and entrepreneurship training project with the implementation of the declaration, improving innovation ability in practical training. According to the characteristics of various disciplines, we establish the "mechanical design and intelligent manufacturing innovation base", "electronic athletics training base", "embedded system and intelligent vehicle innovation base", "electronic waste and Environmental Engineering Research Center" 16 innovation bases. The bases regard students as the main body of the concept to realize students from passive learning into active learning through the effective organization and guide. The innovation bases implement open management; use their own access control systems and websites to enhance the management efficiency and level of the base.

Secondly, the innovation and entrepreneurship activities are carried out based on the project of national college students' innovative experiment plan. The innovative experimental program for undergraduates advocates that project as the carrier, the student as the main body, issues and topics as the core. The innovative experimental program pays attention to the course of the study, to arouse the students' initiative, enthusiasm, causes the student scientific research training at the undergraduate level. Under the guidance of instructors, the student independently complete project design, and the implementation of research conditions, the writing of research report, the exchange of the results. Therefore, our university set up the leading group of students' innovative and entrepreneurial training program and the steering committee and each college establish working group, the daily management of innovative and entrepreneurial training plan will be incorporated into the daily teaching management system; innovative and entrepreneurial training program incorporated into the professional talent cultivation plan, the completion of project to give credits innovation; engineering training center, all kinds of open laboratory are free for all students to provide experimental site and laboratory equipment. Innovative projects are based on a "small" word, so that students can get entrepreneurial inspiration from the daily life of the. For example, activities appeared a "smart awning" project, students' creative inspiration is originate in the actual life, the implementation of the project does not need too much investment, but to solve the people at home, awning can automatic open and close according to the changes in the weather situation, students need to master in the disciplines of mechanical, electronic, industrial design principle, technology and engineering practice ability.

Finally, we establish incubation base of innovation and entrepreneurship to provide methods, funds and venues for students. Our university overcomes the difficulties of the venue, and actively builds students' entrepreneurial practice business street, Business streets equipped with specialized teachers to help student incubator entrepreneurial ideas. At present, just 150 meters of "entrepreneurship practice Street" include total 14 entrepreneurial incubators. These enterprises have been declared, screening, defense experts in competition. The Gold Sea Book Co., Ltd. participated in by the Shanghai Municipal Committee of the Communist Youth League United first financial Youth Venture Investment Service large TV programs the entrepreneurial dream team competition, after five rounds of interviews and tests and, ultimately, get the 100 million financing in the first round. Seven cubic of University Science and Technology Park was built last year. The park use the development pattern of "one school, park, school build, joint innovation", aims to integrate the advantages of resources and gather creative energy, to promote teaching reform and cultivate high skill talents.

\section{GOOD TEACHERS' TEAM OF INNOVATION AND ENTREPRENEURSHIP}

Actively promoting innovation and entrepreneurship teachers team specialization is the key to the implementation of innovation and entrepreneurship education. Our university reform personnel and distribution system to improve the cultivation of teachers of "double teacher type"; make enterprise part-time teacher recruitment, training and assessment management approach; establish industry enterprise technology as the backbone of part-time teachers practice skills course long-term mechanism and dynamic management mechanism. Actively through the alumni and a variety of channels, our university hires entrepreneurs and other entrepreneurs as part-time entrepreneurs to establish a professional and high-quality innovation and entrepreneurship education teacher team.

One is to promote the construction of the double-qualification teacher team. Our university develops and 
clears the sequence structure and content standards about the double-qualification teacher team; and establishes a mechanism to develop the double-qualification teacher team. Our university requires teachers to have more than 1 years of experience in the field of industry and enterprise in 5 years, and puts the teacher's practical experience and technical skills as a necessary condition for the assessment and post appointment. Our university actively organizes teachers in-depth business attachment learning, has introduced a series of management approach to improve the structure of "double teacher type" teachers. Our university stipulates that teachers must be in the first half of the company's specific positions before the promotion to enhance the practical experience. Teachers under the enterprise in the first half of this year is not cursory, but to the production process of in-depth understanding of enterprise, and carry out relevant project, will eventually be the innovation consciousness of the practice in the process of fusion to the daily teaching.

Two is to strengthen the construction of part-time teachers. According to the number of students and the practical teaching task, our university reasonable check and ratify the preparation of teachers, and equip with sufficient quantity and high level of full-time teachers; and actively engage entrepreneurs, entrepreneurs, experts and scholars as part-time teachers who bear certain innovation and Entrepreneurship education teaching task; and encourage the professional teachers in the professional education in organic integration of innovation and entrepreneurship education and teaching content. Our university establishes two-way employment mechanism with experts and technical backbone to improve the management of part-time teachers. According to the different types of part-time teachers, our university clears their qualifications, duties, hiring procedures, assessments and compensation management approach to construct steady part-time teachers. Our university makes full use of kinds of resources and establishes a professional mentor, entrepreneurial expert guidance, professional teachers and counselors, as the main body of innovation and entrepreneurship education guidance team. Model workers, such as Bao Qifan, Li Bin, Xu Xiaoping often come back to develop inspirational education and professional guidance to college students to enhance the students' ability of innovation and entrepreneurship.

Three is to strengthen the training of innovative entrepreneurial teachers. Our university makes policies to encourage and actively guide the professional teachers to participate in guiding students to carry out scientific research innovation activities, entrepreneurial plans, entrepreneurial practice and other innovative entrepreneurial activities. The university regularly organizes teacher training, communication, and constantly improves the level of teaching research and guidance of students' innovation and entrepreneurship practice. The university also strengthens the innovation and entrepreneurship teachers teaching level and improves the construction through special training, testing exercise etc. Such as regular organization innovation and entrepreneurship education teacher training and communication and encourage teachers to actively participate in innovation and entrepreneurship in the field of academic conferences, teaching seminars, create conditions to support teachers to the industry and business testing and training, and constantly improve the professional level and teaching ability of teachers. The implementation of the project enhance the ability of the internationalization of teachers, teachers and managers have to have the overseas application of science and technology university or related colleges and universities, professional institutions of learning, training and work experience. Our university guides the professional teachers and employment guidance teachers to actively carry out theoretical research on innovation and entrepreneurship education, and constantly improve the awareness and ability of innovation and entrepreneurship education in the course of professional education and employment guidance.

\section{CONCLUSION}

In recent years, the practice of innovation and entrepreneurship education has brought a number of popular student bosses. Zhang Lulu in Suzhou Taicang created a 17 employees game company -- Zhuo Digital Technology Co., Ltd.; Shang Xiaohui who carries a " let second-hand book circulate and then use " responsibility and dreams, founded the bookstore which make the second-hand book into network trading platform; Lei Heng has tried to join the Internet business and eventually had founded cloud valve technology company to promote the construction and development of the new media platform, now he have been in service for more than 100 colleges and universities. However, the innovation and entrepreneurship education is a long-term and arduous systematic project. Local university should strengthen theoretical study and practical exploration, form distinctive innovation and Entrepreneurship Talent Training mode, and effectively improve entrepreneurship education quality, enhance the student social adaptation ability and social competence.

\section{REFERENCES}

[1] Jianliang Zou. Exploration of Innovation and Entrepreneurship Education for College Students. [J]. China Higher Education ,2015,(5):56-58.

[2] Li Hui. Orientation of College Students' Innovation and Entrepreneurship Education in the Perspective of Connotation Development. [J]. Higher Education Exploration, 2013,(4):133-136.

[3] Li Ying. Innovation of Teaching Mode of Entrepreneurship Education in Universities Based on Scientific Outlook on Development. [J]. Education and Vocation, 2015,(6):110-111.

[4] Shuchun Liu. Training of Innovative Talents and Reform of Practice Teaching. [J]. Jiangsu Higher Education,2015,(3):119-120.

[5] Liangtao Yang. Research on Cultivation of Innovation Based on Extracurricular Scientific Activities. [J]. continue education research,2013,(11):184-186 